\title{
A comparison of different techniques to assess the biological availability of feed phosphates in pig feeding
}

\author{
B. M. DELlaERT', G. F. V. VAN DER PEET ${ }^{3}$, A. W. JONGBLOED ${ }^{2} \&$ S. \\ BEERS 2
}

1 Agricultural Board, Prinsevinkenpark 19, NL 2585 HK The Hague, Netherlands

2 Research Institute for Livestock Feeding and Nutrition, P.O. Box 160, NL 8200 AD

Lelystad, Netherlands

3 Present address: Research Station for Pig Husbandry, P.O. Box 83, NL 5240 AB Rosmalen, Netherlands

Received 9 March 1990; accepted 14 May 1990

\begin{abstract}
Four hundred and seventy-three piglets were used in three experiments to determine the nutritional value of various feed phosphates and to evaluate the different techniques used. These techniques comprised blood and bone related parameters, the apparent digestibility of phosphorus $(P)$ and the in vitro solubility. Graded levels of $P$ originating from eight feed phosphates were supplemented to a basal diet. The goodness of fit and coefficient of variation were calculated regressing these parameters on supplemented quantity of $\mathbf{P}$ from feed phosphates. In one experiment the retention of $\mathrm{P}$ was measured by comparative slaughter technique and related to the various criteria. Blood parameters did not show a sufficient response to the amount of added $P$. In plasma the alkaline phosphatase activity was not linearly related to the amount of added $P$, while regressing the inorganic $P$ content to the quantity of supplemented $P$ resulted in a low fitness of the model $\left(R^{2}=53 \%\right)$. The results obtained from bone parameters (fat-free dry matter, concentration of ash in fat-free dry matter, amount of ash, concentration of $P$ in ash and bone breaking strength) were better $\left(R^{2}=45-94 \% 0\right)$. There were slight differences in the results using tibia, femur or third and fourth metatarsals. However, the highest degree of fit was found using the apparent digestibility of $\mathbf{P}$ as the dependent variable $\left(R^{2}=96-100 \%\right)$. After relating the criteria to the retention of $P$, again the apparent $\mathrm{P}$ digestibility was the most accurate parameter to determine the biological availability of $P$. Basing the nutritional value of feed phosphates on digestibility of $P$, significant differences could be shown between form and origin of feed phosphate. The values within a type of feed phosphate showed a high repeatability.
\end{abstract}

Keywords: piglets, phosphorus, bone, plasma, alkaline phosphatase, digestibility, feed phosphates

\section{Introduction}

In pigs, utilization of total phosphorus from plant origin ranges from 10 (e.g. rice 
bran) to $50 \%$ (e.g. wheat) (Jongbloed \& Kemme, 1990). For poultry it is more or less $30 \%$. Therefore, inorganic feed phosphates are added to their diets in order to meet the requirements of phosphorus.

Knowledge of the availability of $\mathrm{P}$ in feed phosphates is necessary to compare the nutritional value of $\mathbf{P}$ in different $\mathbf{P}$ sources. This knowledge enables to use a $\mathbf{P}$ source with a high availability in order to reduce the excretion of $\mathrm{P}$ by pigs and poultry as much as possible.

There are different techniques to determine the biological availability of $\mathrm{P}$ from feed phosphates. For this purpose Günther et al. $(1966 / 67 ; 1967 / 68)$ and Günther \& Rosin (1970/71) used blood and bone related criteria. Guéguen (1977) measured the solubility of supplementary phosphorus in vitro, whereas Grimbergen et al. (1985) determined the apparent $\mathbf{P}$ digestibility. However, the different techniques used do not always lead to the same conclusion.

The objective of this study was to determine the nutritional value of various feed phosphates of different types and brands and to evaluate the different techniques used. For that purpose, three experiments have been carried out on piglets.

\section{Materials and methods}

A detailed description of Experiment 1 has already been given by Jongbloed (1987). The onset of the other two experiments is based on that of the first, with some small adaptations. In the following, when the word digestibility is used, apparent absorbability is meant.

\section{Animals and experimental design}

The number of piglets used was 204, 155 and 114 in Experiment 1, 2 and 3, respectively. After weaning at a mean age of five weeks, the piglets remained in the farrowing pen for four days. After that they were moved to the experimental pens and allotted to treatment. The animals were group-housed and group-fed with six or seven animals per pen, except for the third repetition (trial) of Experiment 2 where four to seven animals were housed per pen. No bedding was used and feed and water were available ad libitum.

The general design was practically similar for the three experiments. In each experiment four feed phosphates were tested. Experiments 1 and 2 with $P$ source 8 (disodiumphosphate; DSP) as a reference. Besides, one treatment consisted of the basal diet. Experiment 1 consisted of two replicates and Experiments 2 and 3 of three replicates. Table 1 shows information on the $\mathrm{P}$ sources used and the supplemented concentrations. Evaluation of Experiment 1 led to the conclusion that adding $0.6 \mathrm{~g} \mathrm{P} \mathrm{kg}^{-1}$ hardly supplied any contribution to the model. The levels of $\mathrm{P}$ supplementation in Experiment 2 were 1.2 and $2.2 . \mathrm{g} \mathrm{kg}^{-1}$, respectively. This experiment showed still a linear response of the relevant parameters tested. For that reason in Experiment 3 only $2.0 \mathrm{~g} \mathrm{P} \mathrm{kg}^{-1}$ was supplemented to the basal diet. 
Table 1. Feed phosphates examined and levels of addition. Different numbers refer to different $P$ sources.

\begin{tabular}{llll}
\hline & \multicolumn{2}{l}{ Experiment } & 3 \\
\cline { 2 - 4 } & 1 & 2 & \\
Basal diet & & & 1 \\
Basal diet + & & & 3 \\
Basal diet + & 2 & 2 & 4 \\
Basal diet + & 5 & 5 & 6 \\
Basal diet + & 6 & 6 & \\
Basal diet + & 7 & 8 & - \\
& 8 & 0 & - \\
Levels of addition & & - & 2.0 \\
for each feed phosphate & 0 & 1.2 & \\
(added $\mathrm{P}$ in $\mathrm{g} \mathrm{kg-1)}$ & 0.6 & 2.2 & \\
& 1.2 & & \\
\hline
\end{tabular}

\section{Diets}

The composition of the basal diets in the three experiments is given in Table 2. A semi-synthetic diet was used containing a very low concentration of digestible $P$ (1.0-1.3 $\left.\mathrm{g} \mathrm{kg}^{-1}\right)$. With this level it was possible to add substantial amounts of $\mathrm{P}$ from feed phosphates without exceeding the $\mathrm{P}$ requirements. This is of great importance for the application of the slope ratio technique. In order to calculate the digestibility, chromic oxide was used as an indigestible marker. To obtain a homogeneous distribution of the marker in the diet, chromic oxide was first mixed in a small mixer with maize starch in a weight ratio of 1:3, and subsequently ground in a hammermill through a sieve with a pore size of $0.5 \mathrm{~mm}$. Next this ground mixture was supplemented to and mixed with the other ingredients of the premix. After mixing, the diets were pelleted. The analysed, chemical composition and estimated net energy value of the basal diets are given in Table 3.

\section{Measurements}

The piglets were weighed at weaning, when changing to the trial feed (four days later), weekly during the trial and at the end of the trial. Feed intake was registered weekly. At the end of the trial the piglets were killed and the third and fourth metatarsals were collected from the hind legs. In Experiment 3 the femur and tibia were removed too. In these bones the amount of fat-free dry matter (FFDM), the concentration of ash in it and the concentration of $\mathrm{P}$ in ash were determined. Breaking strength was measured using an Instron Testing Instrument (Crenshaw et al., 1981). In Experiment 3, ash, fat-free dry matter, $P$ content in the whole animal was analysed after the experimental period and also in control animals at the start of 
B. M. DELLAERT, G. F. V. VAN DER PEET, A. W. JONGBLOED AND S. BEERS

Table 2. Feedstuff composition of the basal diets of Experiments 1,2 and $3\left(\mathrm{~g} \mathrm{~kg}^{-1}\right)$.

\begin{tabular}{|c|c|c|c|}
\hline & \multicolumn{3}{|c|}{ Experiment } \\
\hline & 1 & 2 & 3 \\
\hline Babycorn & 400 & 410 & 410 \\
\hline Barley & 200 & 200 & 200 \\
\hline Cane molasses & 40 & 40 & 40 \\
\hline Potato dried pulp & 20 & - & - \\
\hline Alfalfa meal (14-16\% XP) & - & 70 & 50 \\
\hline Soybean oil & 40 & 20 & 30 \\
\hline Potato protein dried & 60 & 60 & 70 \\
\hline Soybean meal & 80 & 65 & 70 \\
\hline Beet pulp dried (20-25\% sugar) & 35 & - & - \\
\hline Acid casein & 70 & 30 & 50 \\
\hline Maize starch & 30.9 & 70.50 & 52.25 \\
\hline Fumaric acid & - & 10 & 10 \\
\hline Choline chloride & 0.25 & 0.25 & 0.25 \\
\hline Minerals and vitamins ${ }^{1}$ & 2.75 & 2.75 & 1.00 \\
\hline Salt & 4.50 & 4.50 & 2.50 \\
\hline Limestone & 14.60 & 15.00 & 12.00 \\
\hline $\mathrm{Cr}_{2} \mathrm{O}_{3}$-starch & 2.00 & 2.00 & 2.00 \\
\hline Total & 1000 & 1000 & 1000 \\
\hline
\end{tabular}

1 Contributed the following in $\mathrm{mg} \mathrm{kg-1}$ of diet: copper sulphate 400, iron sulphate 1500 , manganese oxyde 50 , zinc sulphate 300 , potassium iodide 2 , sodium selenite 13 , vitamin $\mathrm{AD}_{3} 20(500 / 100 \mathrm{IU}$ $\mathrm{mg}^{-1}$ ), vitamin $\mathbf{B}_{1} 2$, vitamin $\mathrm{B}_{2} 10$, vitamin $\mathbf{B}_{12} 35$, vitamin $\mathbf{B}_{6} 2$, vitamin $\mathrm{E} 40$, vitamin $K_{3} 8$, niacin 20 , biotin 3 , calcium panthenotenate 3 , tylan 80 , antioxydant 60 , carrier 452 .

Table 3. Analysed chemical composition estimated and feeding value of the basal diets $\left(\mathrm{g} \mathrm{kg}^{-1}\right)$.

\begin{tabular}{|c|c|c|c|}
\hline & \multicolumn{3}{|c|}{ Experiment } \\
\hline & 1 & 2 & 3 \\
\hline Moisture & 118 & 118 & 113 \\
\hline Ash & 42 & 48 & 42 \\
\hline $\mathrm{XP}$ & 200 & 166 & 170 \\
\hline XL & 58 & 47 & 50 \\
\hline $\mathrm{XF}$ & 39 & 37 & 39 \\
\hline Lysine & 12.5 & 10.3 & 10.6 \\
\hline Cystine + methionine & 7.2 & 6.5 & 6.2 \\
\hline $\mathrm{Ca}$ & 7.4 & 7.2 & 5.7 \\
\hline$P$ & 3.2 & 3.0 & 3.2 \\
\hline Digestible $\mathbf{P}$ & 1.4 & 1.1 & 1.2 \\
\hline $\mathrm{NE}_{\mathrm{f}}(\mathrm{MJ} \mathrm{kg-1})$ & 10.35 & 9.62 & 9.69 \\
\hline
\end{tabular}


the experiment. In this way it was possible to calculate the retention of P. In Experiment 2 , blood samples were taken at the start, in the third and in the fifth week of the experiment. The concentration of inorganic phosphorus $\left(P_{i}\right)$ and the alkaline phosphatase activity were measured in plasma. In the other experiments, blood samples were not collected.

For the digestibility measurements, faeces were collected per pen in the third and fifth week on two days per week. In Experiment 3, faeces were also collected in the fourth week. The faeces of the two days were pooled and analysed. Using $\mathrm{Cr}_{2} \mathrm{O}_{3}$ as a marker, the digestibility of dry matter $\left(\mathrm{d}_{\mathrm{DM}}, \%\right)$ and $\mathrm{P}\left(\mathrm{d}_{\mathrm{P}}, \%\right.$ could be calculated with the following equations:

$$
\begin{aligned}
& \mathrm{d}_{\mathrm{DM}}=\left(1-\frac{[\mathrm{Cr}]_{\text {feed }}}{[\mathrm{Cr}]_{\text {faeces }}}\right) \times 100 \\
& \mathrm{~d}_{\mathrm{P}}=\left(1-\frac{[\mathrm{Cr}]_{\text {feed }} \times[\mathrm{P}]_{\text {faeces }}}{[\mathrm{Cr}]_{\text {faeces }} \times[\mathrm{P}]_{\text {feed }}}\right) \times 100
\end{aligned}
$$

The concentrations in feed and faeces are expressed as $\mathrm{g} \mathrm{kg}^{-1} \mathrm{DM}$.

Analysis of $P$ in collected urine was used to check if the animals were actually fed below their $P$ requirement.

Chemical identification of feed phosphates was carried out by means of solubility in water and solubility in $2 \%$ citric acid. The $\mathrm{P}$ sources were also examined by $\mathrm{X}$ ray diffraction analysis.

\section{Statistical analysis}

For statistical analyses the statistical package Genstat was used. The data were subjected to linear regression analyses using the various criteria as dependent variables and the amount of added $P$ as independent variable (slope ratio technique), in which pen is the experimental unit. All parameters were adjusted for differences between replicates. The basal model was:

$$
Y_{i}=\text { constant }+b_{i} \times\left(g P \text { added to feed }{ }_{i}\right)+b_{j} \times \text { block }_{j}+e_{i j}
$$

in which:

$\mathrm{Y}_{\mathrm{i}}=$ dependent variable

$\mathrm{i}=1 . .5$ for $\mathrm{P}$ source $\mathrm{A} . . . \mathrm{E}$

$\mathrm{j}=1 . . .3$ for repetition $1 . . .3$

For calculating the digestibility of $P$, the digestibility of the dry matter was used as a covariable. Significancy of differences between $P$ sources was tested with Student's $t$-test. 


\section{Results}

All trials were executed without problems, except the first replicate of Experiment 2. The latter was excluded from calculations, because some diarrhoea occurred due to a viral infection.

The results of the analyses of the phosphorus sources are given in Table 4 . There are distinct differences in solubility in water, but minor in citric acid.

The results of X-ray diffraction analyses confirmed the type of $\mathbf{P}$ source.

Analyses of the feeds resulted in a slightly higher $\mathrm{P}$ content than calculated before (at most $0.4 \mathrm{~g} \mathrm{~kg}^{-1} \mathrm{DM}$ higher). The Ca concentration also showed some variation in the various feeds. However, these differences probably did not affect the mineral metabolism.

According to Jongbloed (1987) the concentration of phosphorus in urine of pigs fed above $P$ requirement varies between 150 and $400 \mathrm{mg} \mathrm{l}^{-1}$. Urine of pigs fed below $\mathrm{P}$ requirement contains less than $150 \mathrm{mg} \mathrm{P}^{-1}$. In Experiment 3 the $\mathrm{P}$ concentration in urine collected in five pens was higher than $150 \mathrm{mg} \mathrm{1}^{-1}$. This might be caused by a too high $\mathrm{P}$ intake. However, in this experiment the increased $\mathrm{P}$ excretion also could be due to a too low concentration of calcium in the diet. In the other experiments the $\mathrm{P}$ concentration of all urine samples were below $150 \mathrm{mg} \mathrm{l}^{-1}$.

Linear regression analysis was done of all criteria on the amount of added P. A valuable parameter is one of which a great deal of the variance is explained by the amount of added $P$, combined with a low coefficient of variation (CV).

Table 4 . Solubility ( $\%$ ) of the $\mathbf{P}$ sources used.

\begin{tabular}{lllr}
\hline P source & Exp. & Solubility $(\%)$ in & \\
\cline { 2 - 3 } & & water & $2 \%$ citric acid \\
1 & 3 & 1 & 93 \\
2 & 1 & 6 & 95 \\
& 2 & 4 & 97 \\
3 & 2 & 2 & 100 \\
4 & 3 & 2 & 100 \\
5 & 3 & 49 & 96 \\
& 1 & 70 & 99 \\
6 & 2 & 76 & 100 \\
& 1 & 76 & 100 \\
7 & 2 & 89 & 100 \\
8 & 3 & 81 & 97 \\
& 1 & 76 & 100 \\
\hline
\end{tabular}


In Table 5 the percentage of variance accounted for by the model including coefficients of variation are given. The alkaline phosphatase activity showed a large variation and no linearity occured between the activity and amount of added $P$. Its consequence was that use of the slope ratio technique was not permitted.

The concentration of $P_{i}$ in plasma showed a linear increase due to a rise of $P$ level in the feed. Nevertheless, $\mathrm{R}^{2}$ was low $(53 \%)$, combined with a high coefficient of variation $(13.3 \%) . \mathrm{R}^{2}$ and $\mathrm{CV}$ are based on means of the values in the third and fifth week. A correction for the $P_{i}$ level at the start of the experiment did not decrease the variation.

The best fit of all bone parameters was observed with the amount of $P$ in the

Table $5 . \mathrm{R}^{2}$ and $\mathrm{CV}$ of the regression of several criteria (mean per pen) on $\mathrm{g}$ added $\mathrm{P}$.

\begin{tabular}{|c|c|c|c|c|c|c|}
\hline \multirow[b]{2}{*}{$\mathbf{R}^{2}(\%)$} & Blood & Exp.1 & Exp.2 & \multicolumn{3}{|l|}{ Exp.3 } \\
\hline & $P_{i}$ & -1 & 53 & - & & \\
\hline & & & & & & \\
\hline \multirow[t]{4}{*}{$\mathrm{CV}(\%)$} & $P_{i}$ & - & 13.3 & \multirow{2}{*}{\multicolumn{3}{|c|}{-}} \\
\hline & alk. phosph. & - & $*$ & & & \\
\hline & \multirow[t]{2}{*}{ Bones } & Exp.1 & Exp.2 & \multicolumn{3}{|l|}{ Exp.3 } \\
\hline & & $\mathrm{MT}^{2}$ & MT & MT & $\mathrm{F}$ & $\mathrm{T}$ \\
\hline \multirow[t]{6}{*}{$\mathrm{R}^{2}(\%)$} & FFDM $(g)$ & 47 & 85 & 88 & 88 & 87 \\
\hline & $\operatorname{ash}(\mathrm{g})$ & 55 & 90 & 89 & 93 & 92 \\
\hline & ash $\left(g_{k g-1} \mathrm{ffdm}\right)$ & 72 & * & 79 & 88 & 88 \\
\hline & $P(g)$ & 60 & 91 & 90 & 94 & 93 \\
\hline & $P\left(\mathrm{~g} \mathrm{~kg}^{-1}\right.$ ash $)$ & 45 & 89 & 54 & 70 & 74 \\
\hline & br. strength (kg) & 77 & 80 & 92 & 92 & 89 \\
\hline \multirow[t]{7}{*}{$\mathrm{CV}(\%)$} & FFDM (g) & 8.4 & 7.8 & 6.3 & 7.5 & 7.7 \\
\hline & $\operatorname{ash}(g)$ & 9.0 & 6.6 & 6.7 & 6.8 & 6.9 \\
\hline & ash $(g / k g$ ffdm) & 1.4 & $*$ & 2.4 & 3.1 & 2.8 \\
\hline & $\mathrm{P}(\mathrm{g})$ & 10.0 & 6.3 & 6.5 & 6.6 & 6.7 \\
\hline & $P(g / k g$ ash $)$ & 1.0 & 1.0 & 1.3 & 1.3 & 1.1 \\
\hline & br. strength $(\mathrm{kg})$ & 6.7 & 12.8 & 7.7 & 10.5 & 9.5 \\
\hline & $P$ digestibility & Exp. 1 & Exp.2 & Exp.3 & & \\
\hline \multirow[t]{3}{*}{$\mathrm{R}^{2}(\%)$} & $3^{\text {rd }}$ week & 97 & 98 & 99 & & \\
\hline & $4^{\text {th }}$ week & - & - & 99 & & \\
\hline & $5^{\text {th }}$ week & 99 & 96 & 100 & & \\
\hline \multirow[t]{3}{*}{$\operatorname{CV}(\%)$} & $3^{\text {rd }}$ week & 4.3 & 4.0 & 6.9 & & \\
\hline & $4^{\text {th }}$ week & - & - & 5.3 & & \\
\hline & $5^{\text {th }}$ week & 2.2 & 4.9 & 4.0 & & \\
\hline
\end{tabular}

1 - = not determined, ${ }^{*}=$ not linear related to $\mathrm{g}$ added $\mathrm{P}$.

${ }^{2} \mathrm{MT}=$ metatarsals $3+4, \mathrm{~F}=$ femur, $\mathrm{T}=$ tibia. 
bones. In most cases the femur and tibia showed a slightly higher $\mathrm{R}^{2}$ than the metatarsals, but the CV was often higher. However, the differences between the three bones are very small. In the second experiment the criterion concentration of ash in fat free dry matter was not linearly correlated to the amount of $P$ added to the feed. The $\mathrm{R}^{2}$ of breaking strength varied from 77 to $92 \%$, with hardly any difference between bones. The CV was rather high $(6.7$ to $12.8 \%)$.

The variance in $\mathrm{P}$ digestibility was accounted for by the amount of added $\mathrm{P}$ to a high extent. In addition the $\mathrm{CV}$ was low. This can be concluded from all experiments, both in the third, fourth and in the fifth week.

In Experiment 3 it was possible to calculate the $\mathbf{P}$ retention and this parameter was correlated to the other criteria observed in order to select the best criterion. For all criteria, mean values per pen were taken into consideration. The model was:

$$
P \text { retention }=\text { constant }+b_{i} X+b_{j} \times \text { block }_{j}+e_{i j}
$$

in which: $X=$ criterion, i.e. $d_{p}$, breaking strength, fat-free dry matter, ash, ash in FFDM and $\mathrm{P}$ content in bones.

The $P$ content in bones is totalized over metatarsals, tibia and femur. The apparent $P$ digestibility is calculated as the mean of the measurements in the third, fourth and fifth week. Table 6 shows the results of the regression analysis between $P$ retention

Table 6. $\mathrm{R}^{2}$ and the regression of $\mathrm{P}$ retention $\left(\mathrm{g} \mathrm{kg}^{-1}\right.$ live weight) on various criteria (Exp. 3 ).

\begin{tabular}{lll}
\hline & $\mathrm{R}^{2}(\%)$ & $\mathrm{CV}(\%)$ \\
P digestibility & 78 & 6.7 \\
Breaking strength (Nm) & & \\
- metatarsals & 77.4 & 6.8 \\
- tibia & 58.1 & 9.2 \\
- femur & 68.8 & 8.0 \\
Fat free dry matter (g) & & \\
- metatarsals & 70.8 & 7.7 \\
- tibia & 68.3 & 8.0 \\
- femur & 66.0 & 8.3 \\
& & \\
Ash (g) & & 7.1 \\
- metatarsals & 75.2 & 6.9 \\
- tibia & 76.3 & 7.1 \\
- femur & 75.2 & \\
Ash in FFDM $(\%)$ & & 9.4 \\
- metatarsals & & 6.4 \\
- tibia & 56.9 & 7.2 \\
- femur & 79.7 & 6.9 \\
P in bones (g) & 74.6 & \\
\hline
\end{tabular}


Table 7. The apparent digestibility of phosphorus ( $\%)$ of feed phosphates.

\begin{tabular}{|c|c|c|c|c|c|c|c|c|}
\hline \multirow[t]{3}{*}{ P source } & \multicolumn{8}{|c|}{$\mathrm{P}$ digestibility } \\
\hline & \multicolumn{2}{|l|}{ Exp. 1} & \multicolumn{2}{|l|}{ Exp.2 } & \multicolumn{3}{|l|}{ Exp. 3} & \multirow[t]{2}{*}{ Mean } \\
\hline & week 3 & week 5 & week 3 & week 5 & week 3 & week 4 & week 5 & \\
\hline 1 & - & - & - & - & $70^{c}$ & $54^{c}$ & $64^{c}$ & 63 \\
\hline 2 & $65^{b}$ & $64^{b}$ & $69 c$ & $63 c$ & - & - & - & 65 \\
\hline 3 & - & & $71^{b c}$ & $67 \mathrm{bc}$ & $75^{c}$ & $69 \mathrm{~b} 62^{c}$ & 69 & \\
\hline 4 & - & - & - & - & $82^{b}$ & $69^{b}$ & $71^{b}$ & 74 \\
\hline 5 & $76^{a}$ & $79 a$ & $77 \mathrm{~b}$ & $74^{a b}$ & - & - & - & 76 \\
\hline 6 & $78^{a}$ & $83 \mathrm{ac}$ & $85^{a}$ & $80^{a}$ & $91^{a}$ & $80^{a}$ & $78^{a}$ & 82 \\
\hline 7 & $83^{a}$ & $84^{\mathrm{ac}}$ & - & - & - & - & - & 84 \\
\hline 8 & $96 \mathrm{c}$ & $90 c$ & $90^{a}$ & $85^{a}$ & - & - & - & 90 \\
\hline
\end{tabular}

a,b,c Different characters in the same columm indicate significance of differences $(P<0.05)$.

and both bone parameters and apparent $\mathbf{P}$ digestibility. $\mathrm{P}$ digestibility resulted in a relatively high $\mathrm{R}^{2}(78.0 \%)$ and a low $\mathrm{CV}(6.7 \%)$, although the differences between the various criteria were less marked than obtained from the slope ratio technique.

In contrast with the results obtained from regressing bone parameters on added $P$ (Model 1), the regression of $P$ retention on the parameters of the various bones (Model 2) resulted in a slightly higher $R^{2}$ using metatarsals, except for ash in fatfree dry matter where the tibia was the best. But again in general differences between bones were very small.

Both from the calculated $\mathrm{R}^{2}$ and $\mathrm{CV}$ by means of the slope ratio technique and on the other hand by relating the parameters to the $P$ retention, it appeared that the apparent digestibility of $P$ was the most accurate way of determining the bioavailability of phosphorus. In Table 7 the apparent digestibility of $P$ in the feed phosphates is given. It appears from Table 7 that significant differences can be measured between types of feed phosphates. DSP being used as a reference had the highest $\mathrm{P}$ digestibility.

\section{Discussion}

The performance of the animals did not differ significantly between P sources. Only in Experiment 3, P source 3 showed a significant increase in feed conversion ratio. In most literature dealing with pigs no differences in growth rate, feed intake or feed conversion ratio are found (Noland et al., 1971; Wicke, 1972; Newman \& Elliot, 1976; Bertelson, 1981).

In Experiment 2 the alkaline phosphatase activity and plasma inorganic $\mathbf{P}$ were measured. Boyd et al. (1983) stated that these criteria are valuable in estimating the $P$ availability. However, in this experiment no linear relation was found between the alkaline phosphatase activity and added $P$. Plasma inorganic $P$ increased linearly 
as added $\mathrm{P}$ increased, but $\mathrm{R}^{2}$ was low combined with a high $\mathrm{CV}$. Blood parameters may be influenced to a high extent by diurnal variation and potential stress at the time of sampling. Moreover blood parameters are already the result of the adaptive response of the animal to the treatment, so their usefulness could be low.

A linear effect has been observed between added $\mathrm{P}$ and both digestibility and bone measurements in Experiments 1 and 2. For that reason in Experiment 3 an intermediate $\mathrm{P}$ level was omitted and only high $\mathrm{P}$ levels were used $(2.0 \mathrm{~g} \mathrm{P}$ added to the basal diet). This caused a more accurate assessment of the values of $P$ sources with the same number of observations, resulting in a more discriminating regression with higher $\mathrm{R}^{2}$. Because of the linearity the slope ratio technique for $\mathbf{P}$ digestibility and bone measurements could be applied.

Bone parameters are often used in order to evaluate phosphorus sources (Günther et al., 1966/1967; 1967/1968; Günther \& Rosin, 1970/1971; Koch et al., 1984; Koch \& Mahan, 1985; Cromwell, 1980). These parameters are supposed to be very accurate because about $80 \%$ of the retained quantity of $\mathrm{P}$ is retained in bones. Often bone breaking strength or bone ash percentage ar used, but in this study these criteria did not appear to result in a high $R^{2}$, especially not when regressing added amount of $P$ on these criteria. In fact, in the second experiment the percentage ash in fat-free dry matter was not even linearly related to added $P$.

Off all the bone parameters the $P$ concentration in bones had the highest $R^{2}$ with added $P$. But the results on bone parameters were never as good as when using the digestibility of P. From the results obtained from Experiment 3 it was possible to compare the different bones. There were only slight differences in accuracy and, except for $\mathrm{P}$ in ash, all bones gave almost similar information.

An even better way to evaluate these bones is by using a model in which $\mathrm{P}$ retention is regressed on the various criteria. In this case the differences between bones were very small too: the metatarsals resulted in a slighty lower $\mathrm{R}^{2}$ but lower $\mathrm{CV}$ than the tibia and femur. Koch et al. (1984) and Koch \& Mahan (1985) also concluded that the metatarsals were the most suitable bones to measure the response to dietary phosphorus supply. They compared femur, humerus, third metacarpal and third metatarsal. Fourdin et al. (1987) concluded that the tibia gave comparable results with the fourth metatarsal when using breaking moment. These bones were superior to the third metatarsal and the fibula, which was concluded from an experiment with three levels of added $P$ and six animals per level.

The use of chemical methods to determine the availability of phoshorus from phosphorus sources has also been evaluated. The determination of the solubility in water followed by extraction with a $2 \%$ citric acid solution according to Guéguen (1977) was not discriminative enough in this experiment. Yoshida et al. (1979) observed a high correlation between solubility in $0.5 \%$ citric acid and the biological availability of $P$ in inorganic $P$ sources. They concluded this from trials with chicks and it is doubtful whether this is also true for pigs. To what extent chemical methods can be used to predict the availability of phosphorus sources requires further studies.

The apparent digestibility of $\mathrm{P}$ was the best criterion to measure the response to dietary phosphorus supply. It may be argued that the apparent digestibility of $\mathbf{P}$ of 
the $P$ sources is biased by the faecal endogenous excretion. However, according to Vemmer (1982) there is no great difference in the amount of endogenous $P$ excreted in diets with 3 to $6 \mathrm{~g}$ total $\mathrm{P} \mathrm{kg}^{-1}$. On the other hand it is not very likely that there is a marked influence of source of inorganic feed phosphate used in the diet on the amount of endogenous $P$ excreted.

It can be concluded that the apparent digestibility of $\mathbf{P}$ is by far most the best criterion to determine the nutritional value of feed phosphates. Blood parameters were even worse than bone-related criteria.

Evaluating the feed phosphates by means of digestibility, it was found that distinct differences can be demonstrated between type and origin of feed phosphate for pigs. This was also demonstrated by Grimbergen et al. (1985) when using P digestibility as a criterion. They observed for pigs that there was a strong tendency that the $\mathrm{P}$ digestibility of monocalcium phosphate was superior to dicalcium phosphate hydrated and dicalcium phosphate anhydrous.

The results of this study show, when making use of the $P$ source having the highest availability, a reduction of the $\mathrm{P}$ excretion will take place.

\section{Acknowledgements}

The authors thank Drs P. W. Goedhart for giving advice on the statistical analysis.

\section{References}

Bertelson, A., 1981. Alternate phosphorus source valuable for growing swine. Feedstuffs 53 (40): 12-13.

Boyd, R. D., D. Hall, \& J. F. Wu, 1983. Plasma alkaline phosphatase as a criterion for determining biological availability of phoshorus for swine. Journal of Animal Science 57: 396-401.

Crenshaw, T. D., E. R. Leo, A. J. Lewis, B. D. Moser, \& D. Olson, 1981. Influence of age, sex and calcium and phosphorus levels on the mechanical properties of various bones in swine. Journal of Animal Science 52: 1319-1329.

Cromwell, G. L., 1980. Biological availability of phosphorus for pigs. Feedstuffs 52 (9): 38-42.

Fourdin, A., N. Fontaine \& A. Pointillart, 1987. Effects de la carence et de la surcharge en phosphore sur l'os chez le porc en croissance. Journées de la Recherche Porcine en France 19: 289-294.

Grimbergen, A. H. M., J. P. Cornelissen \& H. P. Stappers, 1985. The relative availability of phosphorus in inorganic feed phosphates for young turkeys and pigs. Animal Feed Science and Technology 13: 117-130.

Guéguen, L., 1977. A propos du controle de la qualité du phosphore des composés minéraux. Elevage Porcin 65: 33-35.

Günther, K. D., R. Witting \& W. Lenkeit, 1966/1967. Untersuchungen über die Skeletentwicklung und die -Mineralisierung in den ersten acht Lebenswochen bei Ferkel. Zeitschrift für Tierphysiologie, Tierernährung und Futtermittelkunde 22: 298-313.

Günther, K. D., R. Witting \& W. Lenkeit, 1967/1968. Untersuchungen über die vergleichende Entwicklung und Mineralisierung der einzelne Skeletteile beim Ferkel in Abhängigkeit von der Ca- und PVersorgung. Zeitschrift für Tierphysiologie, Tierernährung und Futtermittelkunde 23: 106-125.

Günther, K. D., \& G. Rosin, 1970/1971. Über die Ansatzkapazität des Fleischschweines für Mineralstoffe im Verlaufe des Wachtums. 2. Mitteilung. Wachstum und Entwicklung der einzelne Skeletteile. Zeitschrift für Tierphysiologie, Tierernährung und Futtermittelkunde 27: 134-150.

Jongbloed, A. W., 1987. Phosphorus in the feeding of pigs. Effect of diet on the absorption of phosphorus by growing pigs. Doctoral Thesis, Wageningen Agricultural University, $343 \mathrm{pp}$. 
Jongbloed, A. W. \& P. A. Kemme, 1990. Apparent digestible phosphorus in the feeding of pigs in relation to availability, requirement and environment. 1. Digestible phosphorus in feedstuffs from plant and animal origin. Netherlands Journal of Agricultural Science 38: 567-575.

Koch, M. E., D. C. Mahan \& J. R. Corley, 1984. An evaluation of various characteristics in assessing low phosphorus intake in weanling swine. Journal of Animal Science 59: 1546-1556.

Koch, M. E. \& D. C. Mahan, 1985. An evaluation of various characteristics in assessing low phosphorus intake in growing swine. Journal of Animal Science 60: 699-708.

Newman, C. W. \& D. O. Elliott, 1976. Source and level of phosphorus for growing-finishing swine. Journal of Animal Science 42: 92-98.

Noland, P. R., C. A. Baugas, R. N. Sharp \& Z. Johnson, 1971. Sources of phosphorus for growing pigs. Arkansas Farm Results 20: 10.

Vemmer, H., 1982. Der Einfluss der Phosphorversorgung auf die intestinale Absorption von Phosphor bei wachsenden Schweinen. Zeitschrift für Tierernährung und Futtermittelkunde 47: 220-230.

Wicke, G., 1972. Prüfung von neuen Futterphosphaten auf Ihre Phosphorverfügbarkeit für Broiler, Schweine und Lämmer. Archiv für Tierernährung 22: 163-174.

Yoshida, M., Ishikawa, H. Nahajima \& S. Hotta, 1979. Solubility of phosphorus in citric acid solution as on index of biological availability. Japanese Poultry Science 16: 290-292. 